https://nv.nltu.edu.ua

https://doi.org/10.15421/40290604

$@ \bowtie$ Correspondence author

Article received 13.06.2019 p.

Article accepted 27.06.2019 p.

O. O. Klymchuk

УДК 630*221:582.688.3

oleksandraklymchuk@gmail.com

В. І. Ткачук, О. О. Климчук, І. С. Ковальчук

Житомирський національний агроекологічний університет, м. Житомир, Україна

\title{
ДИНАМІКА ВІДНОВЛЕННЯ ЧОРНИЧНИКІВ ПІСЛЯ СУЦІЛЬНИХ РУБОК ГОЛОВНОГО КОРИСТУВАННЯ
}

\begin{abstract}
Лісові екосистеми Житомирського Полісся зазнають постійно зростаючого впливу антропогенних чинників, серед яких значне за обсягами місце займають рубки головного користування. Внаслідок рубок змінюються всі компоненти лісу, зокрема дикорослі ягідники, серед яких найпоширенішим видом у лісах державних лісогосподарських підприємств Житомирського Полісся є чорниця звичайна (14 872 га). Під час рубок головного користування значно пошкоджуються, а згодом частково зникають чорничники внаслідок різкої зміни умов середовища. Процес відновлення є досить тривалим. Динаміку відновлення чорничників проаналізовано за двома важливими показниками - проективне покриття та вегетативна надземна фітомаса чорниці звичайної (Vaccinium myrtillus L.) у материнському фітоценозі та лісових культурах різного віку в умовах вологих соснових суборів Житомирського Полісся. Встановлено, що відновлення чорничників відбувається інтенсивно після змикання соснових культур у віці 6-7 років, проективне покриття чорниці сягає $9,7^{ \pm 0,17} \%$, закінчуючи середньовіковими насадженнями, в яких зазначений показник сягає $67,9^{ \pm 0,26} \%$. Наведено аналіз статистичної значущості різниці середніх значень проективного покриття та величини надземної вегетативної фітомаси на одиниці площі чорничників між різними віковими групами лісових культур і материнськими фітоценозами.
\end{abstract}

Ключові слова: чорничник; продуктивність; суцільні рубки; лісові культури; Житомирське Полісся.

Вступ. Дикорослі ягідні рослини, як і інші види, протягом тисячоліть пристосовувались до певних екологічних умов, виробили певні адаптивні пристосування, які дали їм змогу зайняти екологічні ніші й успішно існувати в них. Процеси пристосування рослин до змін екологічних умов тривають і тепер. Напевно, вони були б успішнішими, якби ці зміни мали послідовний і поступовий характер. Упродовж останніх 50-60 років лісові екосистеми України зазнають значного антропогенного впливу, внаслідок чого спостерігається, як констатують у деяких публікаціях, зменшення площ поширення та продуктивності дикорослих ягідних рослин (Kozjakov, \& Krasnov, 1982). До головних чинників, які призводять до зазначених вище процесів, відносять осушення боліт, суцільні рубки, рекреаційні навантаження та пожежі (Buzun, \& Pristupa, 1989; Krasnov, 1981). Ceред усіх антропогенних чинників, які впливають на стан лісових екосистем Житомирського Полісся, суцільні рубки $є$ найбільш поширеними та значущими. Вони спричиняють значні, майже катастрофічні зміни в режимі освітлення нижніх ярусів лісового фітоценозу, призводять до значного нагріву поверхні грунту, зменшення в ньому запасу вологи, подрібнення та перемішування лісової підстилки з верхніми шарами гумусо- во-елювіального горизонту тощо. Все це вже у перший рік призводить до значних змін у нижніх ярусах лісової рослинності - трав'яно-чагарничковому та моховому. Головним результатом знищення едифікаторного ярусу лісового фітоценозу - деревостану - $€$ зникнення лісового середовища та тимчасове формування більш жорстких та континентальних умов відкритих зрубів.

Метою дослідження є вивчення динаміки проективного покриття та вегетативної надземної фітомаси чорничників у процесі відновлення лісових екосистем після суцільних рубок головного користування.

Аналіз останніх досліджень. Вивчали вплив суцільних рубок головного користування на стан дикорослих ягідників переважно в Україні, Білорусі та Прибалтиці. Дослідники були одностайні, що в період проведення рубок пошкоджуються і знищуються ягідні рослини, перемішуються верхні горизонти грунту (Buzun et al., 1989). Пізніше на стан ягідників впливають лісокультурні роботи, що призводять, разом з рубками, до знищення ягідних рослин на 80-90\% площі (Krasnov, 1985). До рослин, які найбільше потерпають від суцільних рубок, вчені віднесли чорницю та брусницю. Чорниця $є$ тіньовитривалою рослиною, оптимальні умови для зростання складаються за повноти деревостану

Інформація про авторів:

Ткачук Володимир Ілліч, д-р с.-г. наук, професор, кафедра загального лісівництва. Email: vtkachuk1960@gmail.com; https://orcid.org/0000-0002-4012-4396

Климчук Олександра Олександрівна, канд. с.-г. наук, доцент, кафедра загального лісівництва. Email: oleksandraklymchuk@gmail.com; https://orcid.org/0000-0002-4429-6072

Ковальчук Ірина Сергіївна, здобувач, кафедра загального лісівництва. Email: kovalchukis27@gmail.com; https://orcid.org/0000-0002-4109-6040

Цитування за ДСТУ: Ткачук В. І., Климчук О. О., Ковальчук І. С. Динаміка відновлення чорничників після суцільних рубок головного користування. Науковий вісник НЛтУ України. 2019, т. 29, № 6. С. 24-27.

Citation APA: Tkachuk, V. I. , Klymchuk, O. O. , \& Kovalchuk, I. S. (2019). Dynamics of the recurrence of blueberry bushes after heavy use of whole-tree clear-cutting. Scientific Bulletin of UNFU, 29(6), 24-27. https://doi.org/10.15421/40290604 
0,6-0,8 (Krasnov \& Orlov, 1989). Окрім впливу технічних засобів у період рубок (звалювально-пакетувальної техніки, трелювальних тракторів, сучкорізних машин з допомогою яких проводяться рубки), на неї негативно впливає пряме сонячне опромінення, яке призводить до гибелі навіть тих рослин, які збереглися після рубки.

Спостереження, проведені в умовах Полісся Украіни, свідчать, що необхідно 20-30 років, щоб чорничник відновився після суцільних рубок головного користування та лісокультурних робіт, але на деякій частині площ ягідники не відновлюються і за зазначений період. Дослідники запропонували проводити у стиглих лісових насадженнях із високопродуктивними ягідниками поступові рубки, які б забезпечували збереженість, успішний розвиток і плодоношення чорниці (Krasnov, 1985). На основі існуючих наукових досліджень щодо вивчення впливу суцільних рубок на стан ягідних рослин у Росії розробили "Методику оцінки впливу рубок головного користування і лісовідновлення на збереженість дикорослих ягідників 3 метою створення системи лісівничих вимог до них" (Pronin \& Pronina, 1989). У документі регламентували деякі технологічні моменти проведення рубок, які забезпечували певну збереженість ягідних рослин.

Матеріали та методи дослідження. Закладання тимчасових пробних площ для оцінки впливу суцільних рубок головного користування на продуктивність ягідників проводили за загальноприйнятими методиками, описаними у "Польовій геоботаніці" (Korchagin, 1964; Lavrenko, 1959; Iunatov, 201). Оцінку продуктивності дикоростучих ягідників проводили за методикою С. М. Козьякова (1982), а виявлення ресурсів дикорослих чорничників, їхніх площ та поширення - за М. Д. Даніловим (Danilov, 1973). Проективне покриття ягідників та складові врожайності визначали способом закладання постійних та тимчасових пробних площ за загальноприйнятими методиками (Tiulin, 1970). Вивчення продуктивності ягідних рослин проводили в межах 23 пробних площ розміром 1 га (розміром $100 \times 100$ м) на облікових ділянках з використанням сітки Раменського площею $1 \mathrm{~m}^{2}$. Облікові ділянки розташовувались рівномірно в кількості 20 шт. на пробній площі. Величину надземної фітомаси визначали після суцільного іï зрізання на облікових ділянках і висушування до повітряно сухого стану.

Під час аналізу експериментальних даних проводили статистичну обробку первинних даних за допомогою стандартних пакетів програм Excel та "Statistica 6.0" загальноприйнятими методами (Lakin, 1977; Urbakh, 1964, 2000). Застосовували аналіз простих статистик, кореляційний, регресійний та дисперсійний аналізи.

Результати дослідження та їх обговорення. На тимчасових пробних площах, закладених у материнських ценозах та в лісових культурах різного віку у вологих соснових суборах, ми проаналізували динаміку розвитку чорничників - надземної вегетативної фітомаси та проективного покриття.

У материнських ценозах, віком 100-130 років, до проведення суцільних рубань головного користування проективне покриття чорниць знаходилося у діапазоні від 55,2 $2^{ \pm 0,95} \%$ на ТПП-1ч до $67,4^{ \pm 0,46} \%$ на ТПП-4ч. У перший рік після рубки, як вже зазначали вище, чорниці практично випадають зі складу трав'яно-чагарничкового ярусу. На пробних площах ТПП-17 ч, ТПП-18ч та
ТПП-20ч їхнє проективне покриття не перевищувало $0,1 \%$. Така сама ситуація зберігалася і в подальші кілька років, зокрема цей показник коливався у соснових культурах віком 2-3 роки в діапазоні від $0,1^{ \pm 0,00} \%$ на ТПП-14ч до $0,3^{ \pm 0,09} \%$ на ТПП-15 ч. Типовим при цьому було значне варіювання проективного покриття чорниць ( $V=123,03 \%)$.

У віці змикання соснових культур (6-7 років) проективне покриття чорниць на тимчасових пробних площах збільшилося близько у 100 разів, порівняно з попереднім періодом, і змінюється у діапазоні від 9, $0^{ \pm 0,20} \%$ на ТПП-13ч до $11,0^{ \pm 0,18} \%$ на ТПП-12ч. При цьому на досліджених тимчасових пробних площах варіювання цього показника було досить низьким $(V=7,22-$ $10,44 \%$ ), як і величина відносної похибки середнього значення $(p=1,62-2,33 \%)$. У лісових культурах віком 15-18 років середні значення проективного покриття чорниць характеризуються значною амплітудою значень між пробними площами - від 9,3 $3^{ \pm 0,19} \%$ на ТПП10 до $19,0^{ \pm 0,24}$ на ТПП-9ч. У культурах сосни звичайної II вікової групи молодняків (29-36 років) середнє проективне покриття чорниць знаходили у вузькому діапазоні значень - від 53, $5^{ \pm 0,55} \%$ на ТПП-23ч до $59,9^{ \pm 0,90} \%$ на ТПП-22ч. Як і в попередніх вікових групах, у цій групі варіювання досліджуваного показника на пробних площах є незначним $(V=4,56-6,80 \%)$, а відносна похибка середнього значення - малою $(p=1,02-1,52)$. У середньовікових культурах сосни проективне покриття чорниць знаходилося у діапазоні від $67,8^{ \pm 0,46} \%$ на ТПП-5ч до $68,1^{ \pm 0,42} \%$ на ТПП-6ч.

Описані вище закономірності динаміки проективного покриття чорничників у культурах сосни звичайної різного віку узагальнили на рисунку.

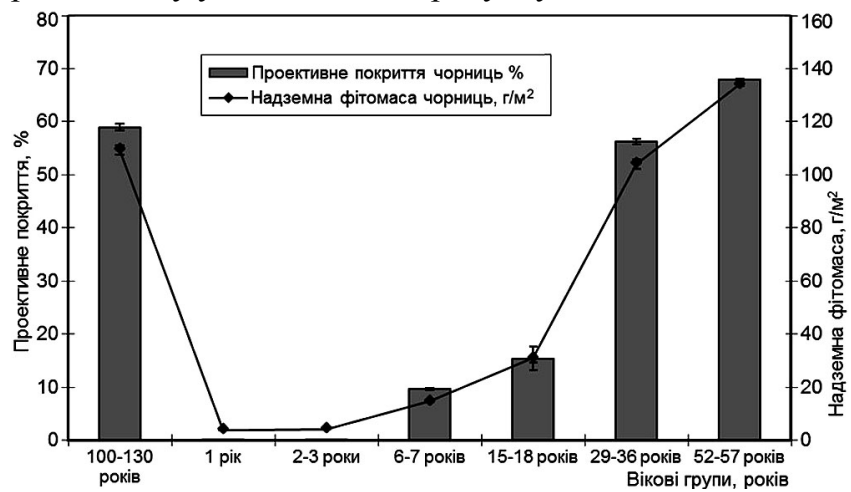

Рисунок. Динаміка проективного покриття та надземної фітомаси чорничників у культурах сосни звичайної різного віку

Дані рисунку наочно свідчать про те, що інтенсивне відновлення чорничників починається після змикання соснових культур у віці 6-7 років, коли чорниці характеризуються середнім проективним покриттям $9,7^{ \pm 0,17} \%$, закінчуючи середньовіковими насадженнями, в яких зазначений показник сягає $67,9^{ \pm 0,26} \%$. Відзначено цікавий факт: проективне покриття чорничників у середньовікових культурах сосни звичайної було більшим у 1,2 раза, порівняно із стиглими та перестійними сосновими деревостанами.

Інформативними є статистичні дані, які характеризують статистичну значущість різниці середніх значень проективного покриття чорничників між різними віковими групами лісових культур і материнськими фітоценозами. Зокрема виявили, що проективне покриття чорничників у материнських фітоценозах та в лісових 
культурах сосни у всіх досліджених вікових групах відрізнялися істотно на $95 \%$ довірчому рівні. Окрім цього, спостерігаємо закономірну тенденцію збільшення статистичної значущості різниці зазначеного показника між материнськими фітоценозами і лісовими культурами - від пристигаючих $\left(F_{\text {факт. }}=128,30>F_{0,95}(1 ; 139)\right.$ $=3,91 ; p=0,00)$ до молодняків II вікової групи та молодняків віком $2-3$ роки $\left(F_{\text {факт. }}=8135,80>>F_{0,95}(1 ; 119)\right.$ $=3,92 ; p=0,00)$.

Отже, за результатами аналізу дисперсійної матриці, середні значення проективного покриття чорниць між всіма віковими групами лісових культур відрізнялися істотно на $95 \%$ довірчому рівні $\left(F_{\text {факт. }}>>F_{0,95}\right)$. Також встановлено для материнського фітоценозу, що статистична значущість різниці середніх значень цього показника в кожній віковій групі культур зростала від середньовікових культур до молодняків. Винятком були лісові культури молодшого віку (однорічні та 2-3-річні), статистична різниця середніх значень проективного покриття чорничників в яких не була істотною на $5 \%$ рівні значущості $\left(F_{\text {факт. }}=0,00\right)$.

Аналіз величини вегетативної надземної фітомаси чорниць на одиниці площі в лісових культурах сосни звичайної різного віку, як і аналіз проективного покриття чорниць, дає змогу простежити динаміку відновлення чорничників після суцільних рубок деревостану. Так, у стиглих та перестійних соснових лісах із чорнично-зеленомоховим покривом величина вегетативної надземної фітомаси чорниць коливалася від 97,4

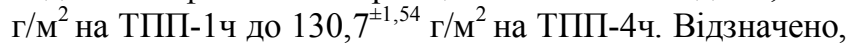
що зазначений показник характеризувався дещо більшою варіабельністю, порівняно $з$ проективним покриттям. Так, на пробних площах цієї вікової групи величина коефіцієнта варіації цього показника знаходиться у діапазоні 7,70-9,80 \%, а відносна похибка середнього значення - 1,17-2,19\%.

Як зазначено вище, вже у перший рік після суцільних рубок деревостану проективне покриття чорниць значно зменшилося, що позначилося у надземній фітомасі чорниць на одиниці площі. Величина цього показника в 1-річних лісових культурах характеризується вузькою амплітудою середніх значень - від $3,68^{ \pm 0,027}$

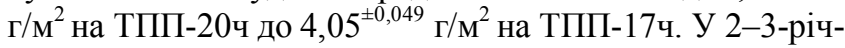
них соснових культурах досліджуваний показник також був невисоким і знаходився у діапазоні від $3,77^{ \pm 0,022}$ г/м² на ТПП-16ч до 4,95 $5^{ \pm 0,083} \Gamma / \mathrm{M}^{2}$ на ТПП-14ч. У процесі росту та змикання лісових культур сосни звичайної поступово відновлюється лісове середовище, відбувається поступове збільшення вегетативної надземної фітомаси чорниць, яка на тимчасових пробних площах

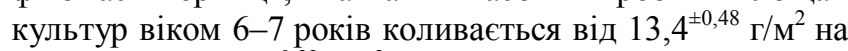
ТПП-11ч до $16,1^{ \pm 0,32}$ г/м² на ТПП-12ч. Для цього показника у зазначеній віковій групі тимчасових пробних площ спостерігаємо варіювання значень у межах $V=8,92-15,95 \%$, а величини відносної похибки середнього значення $-p=1,99-3,57 \%$. Після змикання лісових культур відновлення чорничників значно прискорюється, і в молодих соснових культурах надземна фітомаса чорниць є меншою у 4-5 разів, порівняно 3 материнськими ценозами до рубок. Так, у соснових культурах віком 15-18 років цей показник знаходився у

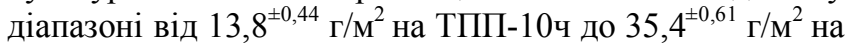
ТПП-9ч $з$ коефіцієнтом варіювання на пробних площах у межах 7,69-15,11\% та відносною похибкою середніх значень у межах 1,72-3,38 \%.

У культурах сосни звичайної другої вікової групи величина надземної вегетативної фітомаси чорниць майже сягає вихідних значень, характерних для материнських фітоценозів середньовікових і стиглих сосняків. Зокрема у віковій групі 29-36 років величина цього показника має амплітуду від 99, $0^{ \pm 2,56} \Gamma / \mathrm{M}^{2}$ на ТПП-23ч до $114,0^{ \pm 2,81} \Gamma / \mathrm{M}^{2}$ на ТПП-22ч та характеризується середнім рівнем варіювання $(V=11,00-11,82 \%)$ та високою точністю визначення середніх значень ( $p=2,46-$ $2,64 \%$ ). У середньовікових культурах сосни звичайної відбувається повне відновлення надземної фітомаси чорниць. Так, у соснових насадженнях у віці 52-57 років середні значення вегетативної надземної фітомаси коливаються від $129,6^{ \pm 1,49}$ г/ $\mathrm{m}^{2}$ на ТПП-5ч до $136,7^{ \pm 0,80} \Gamma / \mathrm{M}^{2}$ на ТПП-6ч, а також характеризуються низьким рівнем варіювання значень на пробних площах $(V=2,63-5,13 \%)$ та низькими значеннями відносної похибки середніх значень $(p=0,59-1,15)$.

Узагальнені дані динаміки вегетативної надземної фітомаси чорниць у соснових культурах різного віку у вологих суборах (див. рисунок) демонструють важливі закономірності. Так, спостерігаємо помітний паралелізм між проективним покриттям чорничників та їх вегетативною надземною фітомасою у процесі відновлення після суцільної рубки головного користування. Останній показник істотно зменшується від $109,4^{ \pm 1,73} \Gamma / \mathrm{M}^{2} \mathrm{y}$ пристигаючих та стиглих сосняках до проведення рубки до $3,9^{ \pm 0,03} \Gamma / \mathrm{M}^{2}$ у лісових культурах у перший рік після рубки, до $14,6^{ \pm 0,27}$ г/м² у віці змикання лісових куль-

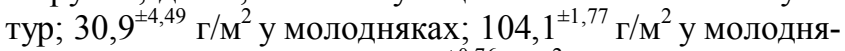
ках 2-ї вікової групи та $134,1^{ \pm 0,76} \Gamma / \mathrm{M}^{2}$ у середньовікових соснових культурах. Відзначено, що у середньовікових лісових культурах цей показник є більшим у 1,23 раза, порівняно з материнськими фітоценозами. Найбільш вірогідно, це зумовлене різницею у віковій структурі парціальних кущиків чорниць у ценозах зазначеного віку, зокрема переважанням у старих сосняках парціальних кущиків віком 10 років і старше, а в середньовікових віком 6-8 років. Останні характеризуються більшою кількістю листя на 1 кущик.

Значний як теоретичний, так і практичний інтерес має статистична оцінка значущості відмінностей середніх значень вегетативної надземної фітомаси чорниць у лісових культурах досліджених вікових груп. Середні значення цього показника відрізняються істотно на $95 \%$ довірчому рівні між материнським фітоценозом та всіма віковими групами лісових культур $\left(F_{\text {факт. }}=4,51-\right.$ $\left.2772,37>F_{0,95}(1 ; 139)=3,91 ; p=0,00-0,034\right)$, а також у розрізі вікових груп $\left(F_{\text {факт. }}=13,11-4260,80>F_{0,95}(1 ; 119)\right.$ $=3,92 ; p=0,0000-0,0004)$. Як і для проективного покриття чорниць, спостерігаємо загальну закономірність значне зменшення статистичної значущості відмінностей середніх значень вегетативної надземної фітомаси чорниць між материнськими фітоценозами та лісовими культурами зі збільшенням їхнього віку. Так, наприклад, значення критерію Фішера у дисперсійних парах лісових культур зменшувалися від 2772,37 у віці лісових культур 1 рік до 136,64 у віці лісових культур 5257 років $(p=0,00)$. Аналогічно стається і в дисперсійних парах між всіма віковими групами лісових культур. Дані рисунку також дають змогу зробити практичний висновок про те, що чорничники, як джерела заго- 
тівлі цінної лікарської сировини - листяних пагонів чорниць, мають промислове значення для заготівлі у культурах сосни звичайної, починаючи 3 молодняків II вікової групи. Доцільно проводити промислову заготівлю пагонів чорниць саме в культурах сосни звичайної II вікової групи.

Висновки. Інтенсивне відновлення чорничників починається після змикання соснових культур у віці 67 років, коли чорниці характеризуються середнім проективним покриттям $9,7^{ \pm 0,17} \%$, закінчуючи середньовіковими насадженнями, в яких цей показник сягає $67,9^{ \pm 0,26} \%$.

Після суцільних рубок головного користування проективне покриття у чорничників відновлюється у молодняках II вікової групи.

Спостерігаємо помітний паралелізм між проективним покриттям чорничників та їх вегетативною надземною фітомасою у процесі відновлення після суцільної рубки головного користування.

Листяні пагони чорниць, як лікарська сировина, мають найбільше промислове значення у середньовікових соснових насадженнях.

У середньовікових лісових культурах вегетативна надземна фітомаса чорниць $є$ більшою в 1,23 раза, порівняно з материнськими фітоценозами.

\section{Перелік використаних джерел}

Buzun, V. A., \& Pristupa, G. K. (1989). The influence of aggregate technology on the soil cutting conditions. Kharkiv: UkrNIILHA. [In Russian].
Buzun, V. A., Krasnov, V. P., Pristupa, G. K., \& Turchak, F. N. (1989). Forest management and reforestation in Polisya of Ukrainian SSR. Moscow: Minlesprom SSSR. [In Russian].

Danilov, M. D. (1973). Sposoby uchjota urozhajnosti i vyjavlenija resursov dikorastushhih plodovo-jagodnyh rastenij i sedobnyh gribov. Joshkar-Ola. [In Russian].

Iunatov, A. A. (2019). Establishment of environmental profiles and test plots. Polevaja geobotanika, 3, 9-35. [In Russian].

Korchagin, A. A. (1964). Species (floristic) composition of plant communities and methods of its study. Polevaja geobotanika, 3, 39-59. [In Russian].

Kozjakov, S. N., \& Krasnov, V. P. (1982). Resources of the main wild-growing berry plants of the forests of Polisya of Ukraine and the prospects for their development. Rastitelnye resursy, 18(4), 553-557. [In Russian].

Krasnov, V. P. (1981). The influence of anthropogenic factors on the growth of blueberries in the Ukrainian Polissya. Lesnoe hozjajstvo, 3, 64-68. [In Russian].

Krasnov, V. P. (1985). Impact of main felling on bilberry bushes. Lesnoe hozjajstvo, 4, 59-64. [In Russian].

Krasnov, V. P., \& Orlov, A. A. (1989). Influence of closeness of plantations on the fruiting of berry plants of the cowberry family. Ekologicheskie svojstva brusnichnyh jagodnyh rastenij v prirode $i$ kulture, 63-64. Riga: AN Lat. SSR. [In Russian].

Lavrenko, E. M. (1959). The main patterns of plant communities and ways to study them. Polevaja geobotanika, 1, 13-70. [In Russian].

Pronin, M. I., \& Pronina, E. A. (1989). Methods of assessing the impact of primary felling and reforestation on the safety of wild berries in order to create a system of forest management requirements for them. Moscow: VNIILM. [In Russian].

Tiulin, S. Ia. (1970). Some results of work on accounting yields of blueberries and marsh cranberries. Rastitelnye resursy, 7(4), 541549. [In Russian].

V. I. Tkachuk, O. O. Klymchuk, I. S. Kovalchuk

Zhytomyr National Agroecological University, Zhytomyr, Ukraine

DYNAMICS OF THE RECURRENCE OF BLUEBERRY BUSHES AFTER HEAVY USE OF WHOLE-TREE CLEAR-CUTTING

Whole-tree logging is the main type of cutting for the current usage in Zhytomyr Polissya. As a result of these forest cuts all the elements of the forest ecosystems are changing radically, including herbaceous plants and shrubs. Wild berries play an important role there. The study of the dynamics of the projective covering and vegetative overground phytomass of blueberries in the process of forest ecosystem restoration after the whole-tree clear-cutting of the main use is an important task for the further development of methods, which help promote the restoration of forest phytocoenoses in general. For conducting of this research some temporary trial methods have been approved according to generally accepted ones, which are described in "Field Geobotany" (Lavrenko, 1959; Unatov, 1964; Korchagin, 1964, etc.). The essesment of the wild-berries bushes productivity was conducted according to S. M. Kozyakova's method (1982), but the resources discovery of wild blueberry bushes, their areas and extension was conducted according to M. D. Danilov's method (1973). Projective coverage of berry bushes and yields components was determined according to the method proposed by S. Ya. Tiulin in 1970. It was established that intense recovery of blueberry bushes began after the closure of pine crops at the age of 6-7 years when blueberries are characterized by an average projective covering of $9.7^{ \pm 0.17} \%$, and ends with ripe plantations, in which the mentioned index reaches $67.9^{ \pm 0.26} \%$. The projective coverage of blueberry bushes in middleaged crops of Silver pine was 1.2 times bigger in comparison with ripe and overgrown pine trees. Average values of blueberry projective coverage in all the age groups of forest crops differ significantly $(95 \%)$ on confidence level $\left(F_{\text {fact. }}>>F_{0.95}\right)$. It was also estimated that for maternal phytocoenosis the statistical significance of the average values difference of this particular indicator in each age group of crops increased from middleaged to young. Younger forest crops (1 year old and 2-3 years old) were the exception, the statistical difference of average values of the projective coverage of blueberries in which was not significant at $5 \%$ level of significance $\left(F_{\text {fact }}=0.00\right)$. A noticeable parallelism is observed between the blueberries projective coverage and their vegetative phytomass in the process of recovery after cutting. In the process of pine growing and closing the forest environment is gradually restored, although we can observe gradual increase in the vegetative overground phytomass of blueberries, which ranges from $13.4^{ \pm 0.48} \mathrm{~g} / \mathrm{m}^{2}$ at the CCI- $11 \mathrm{ch}$ to $16.1^{ \pm 0,32} \mathrm{~g} / \mathrm{m}^{2}$ at CCI- $12 \mathrm{~h}$ at the temporary trial areas of crops aged 6-7 years. After the closure of forest crops, the recovery of blueberries is significantly accelerated, and young pine crops have the above-ground phytomass of blueberries which is $4-5$ times less in comparison with maternal cenoses to cutting. Pine plants of the second age group have the value of the above-ground vegetative phytomass of blueberries which almost reaches the initial values $\left(104.1^{ \pm 1.77} \mathrm{~g} / \mathrm{m}^{2}\right)$ and this is the characteristics of maternal phytocenoses of middle aged and ripe pine forests. A complete restoration of above-ground phytomass of blueberries is observed in middle aged pine-tree cultures. This figure is 1.23 times bigger in comparison with maternal phytocoenoses. Previously conducted researches can be used in programs of preservation measures and restoration of species biodiversity of forest ecosystems.

Keywords: blueberry bushes; productivity; forest crops; whole-tree logging; Zhytomyr Polissya. 